\title{
Transdisiplinaritas Dalam Pendidikan Islam
}

\section{Purniadi Putra}

Institut Agama Islam Sultan Muhammad Syafiuddin Sambas Kalimantan baratusupurniadi@yahoo.com

Abstract: Human as mysterious creatures cannot if only be approached by a scientific discipline, they must be understood in an interdisciplinary manner. In writing this journal explaining the possibility of Islamic education has a transdisciplinary meaning to eliminate the separation between general science and the science of religion and all the knowledge developed is related to one another. The method used is the method of discourse analysis and content. The way in which a number of literatures is discussed and analyzed is based on the direction and purpose of the transdisciplinary concept. The results of the discussion in the context of the transdisciplinary Islamic education curriculum must be developed to be holistic in nature that can cover a variety of problems inherent in humans and their development. The ability to achieve it in transdisciplinary Islamic education is the ability to see the world as a value system, each of which has different tasks and functions but still interconnected. This interconnection connection system must be placed in the framework of faith and noble character.

Abstrak: $\quad$ Manusia sebagai makhluk misterius tidak bisa jika hanya didekati oleh satu disiplin ilmu, maka harus dipahami secara interdisipliner. Dalam penulisan jurnal ini menjelaskan kemungkinan pendidikan Islam memiliki makna transdisipliner untuk menghilangkan pemisahan antara ilmu 
pengetahuan uтum dengan ilmu agama dan semua pengetahuan yang dikembangkan saling terkait satu sama lain. Metode yang digunakan adalah metode analisis wacana dan isi. Cara dimana sejumlah literatur dibahas dan dianalisis didasarkan pada arahan dan tujuan konsep transdisipliner. Hasil diskusi dalam konteks kurikulum transdisiplin pendidikan Islam harus dikembangkan harus bersifat holistik yang bisa mencakup berbagai permasalahan yang melekat pada manusia dan perkembangannya. Kemampuan untuk mencapainya dalam pendidikan Islam transdisipliner adalah kemampuan melihat dunia sebagai sistem nilai yang masing-masing memiliki tugas dan fungsi yang berbeda namun tetap saling berhubungan. Sistem koneksi interkoneksi ini harus ditempatkan dalam kerangka iman dan karakter mulia.

Kata kunci: Transdisipliner, Concept, Education, Islamic Education

\section{A. Pendahuluan}

Pendidikan Islam dengan berbagai karakteristiknya yang penuh dinamika tidak bisa dilepaskan dari persoalan-persoalan yang melingkupinya, mulai dari persoalan sistem yang dikembangkan, dikotomi keilmuan, kurikulum, hingga orientasi output SDM (Sumber Daya Manusia) yang diharapkan. Persoalan-persoalan tersebut menjadi problem menahun yang mestinya dapat dicarikan solusinya sebaik dan secepat mungkin. Selama ini apabila dihubungkan dengan disiplin keilmuan yang dikembangkan, ada anggapan bahwa pendidikan Islam identik dengan ilmu-ilmu agama saja. Padahal sejatinya, pendidikan Islam itu membelajarkan dan mengembangkan berbagai disiplin ilmu secara total. Pendidikan Islam idealnya tidak hanya sebatas menanamkan spirit ritual dalam menjalani pelbagai dinamika kehidupan, tetapi juga mampu memberi makna dengan beragam aktivitas sehingga menyumbang secara aktual terhadap peradaban.

Problematika keilmuan di satu sisi menjelaskan suatu disiplin ilmu tertentu, karenanya suatu ilmu dapat dipandang/ditelaah berdasarkan perspektif tertentu, namun di sisi lain untuk dapat melihat secara utuh, paradigmatik dan komprehensif maka sebuah konsep keilmuan memerlukan telaah dari berbagai perspektif. Memahami suatu persoalan tidak cukup hanya dengan pendekatan satu disiplin 
ilmu tertentu, melainkan juga harus melibatkan berbagai ilmu/lintas disiplin ilmu secara sinergis (transdisciplinary synergy). Dengan demikian, persoalan-persoalan yang menimpa dunia pendidikan Islam harus didekati, dipahami dan ditelaah dengan pendekatan transdisipliner agar diperoleh pandangan yang paradigmatik dan komprehensif juga. Inilah yang dimaksud dengan pendidikan Islam transdisipliner.

Dalam rangka mensinergiskan pendidikan Islam transdisipliner maka diperlukan sistem kurikulum yang juga transdisipliner, menerabas lintas batas dan holistik. Hal ini dapat dijadikan sebagai alternatif jawaban atas tumpang tindihnya problem yang diakibatkan oleh ketidaksinkronan antara teori dengan kebutuhan masyarakat. Kurikulum setidaknya harus dikembangkan dari berbagai perspektif keilmuan dan bersumber pada realitas kehidupan masyarakat yang kompleks, cenderung tidak pasti dan cepat berubah. Oleh sebab itu, artikel ini berupaya memformulasikan suatu pendidikan Islam yang sifatnya transdisipliner. Pendidikan Islam „modele ini selain melibatkan berbagai disiplin ilmu juga berorientasi pada pengembangan SDM yang siap menghadapi tantangan zaman yang serba berubah dan kompleks. Dengan demikian, kurikulum yang holistik dan analisis yang berkarakter paradigmatis menjadi suatu keharusan saat menerapkan ,,model ${ }^{\text {le }}$ pendidikan Islam transdisipliner. Pendekatan yang digunakan untuk membahas persoalan di atas adalah analisis wacana. Pembahasan dilakukan dengan cara menganalisis sumber dan nilai-nilai ideologis pendidikan Islam baik secara teologis, filosofis, sosiologis dan antropologis.

Dalam permasalahan pendidikan banyak beragam disiplin yang berpengaruh dalam setiap sistem. Aktivitas pendidikan dilakukan oleh spesialis dalam berbagai bidang pendidikan. Berkembangnya isu pendidikan yang terpisah-pisah menjadikan makin terkotak-kotaknya sistem pendidikan saat ini. Dalam mengantisipasi isu tersebut, maka diperlukan sebuah pendekatan, dan pendekatan yang sesuai adalah pendekatan transdisiplin, karena produksi ilmu pengetahuan adalah suatu proses sosial yang mengalami diseminasi secara global maupun lokal melalui berbagai bentuk dan tempat, maka di masa yang akan datang akan terjadi rekonfigurasi ilmu pengetahuan.

Dengan demikian, maka dalam menghadapi berbagai masalah kehidupan di alam semesta ini, tak cukup civitas akademika 
dipersiapkan dengan satu disiplin saja berdasarkan kognisinya semata, melainkan diperlukan orientasi transdisipliner melalui interpenetrasi antara rasio, emosi, intuisi dan cipta talent. Ini tidak berarti bahwa satusatunya disiplin tidak perlu diperdalam secara intensif, melainkan kedalaman intensivitas maupun eksentivitas ilmu tersebut mencari berbagai fungsi keterkaitannya dengan aneka dimensi kehidupan, sehingga terwujud ilmu pengetahuan yang terobos menerobos. Perkembangan peradaban dunia yang semakin global saat ini menjadikan rumitnya persoalan sehingga segala persoalan yang ada tersebut tidak mungkin diselesaikan dengan satu disiplin ilmu saja tetapi memerlukan multi disiplin untuk memecahkannya.

Dalam memecahkan masalah pendidikan jika kita hanya menggunakan monodisiplin, kita akan berhadapan dengan berbagai kelemahan yang muncul di mana kita hanya memahami disiplin ilmu itu saja tanpa memahami disiplin ilmu lain yang dapat dimanfaatkan untuk melengkapi disiplin ilmu yang kita pahami. Dunia akademik saat ini ditandai dengan keberadaan disiplin ilmu yang saling terpisah. Integrasi oleh karenanya merupakan kata kunci yang diperlukan untuk meningkatkan pemahaman.

Upaya untuk mengatasi masalah-masalah global yang bersifat multi sektoral memerlukan pendekatan transdisiplin. Pendekatan transdisipliner sebagai ruang intelektual merupakan wadah dimana isuisu tersebut dibahas sehingga berbagai permasalahan tersebut dapat dianalisis dan di implementasikan.

Berdasarkan paparan di atas, jurnal ini akan membahas tentang mengkaji dan menganalisis mengenai transdisiplinaritas dalam pendidikan Islam.

\section{B. Transdisiplinaritas}

Transdisiplinaritas (transdisciplinarity) dan/atau transdisipliner (transdisciplinary) merupakan istilah yang digunakan dalam dunia keilmuan sebagai sebuah pendekatan multiperspektif. Istilah-istilah lain yang disandarkan pada kata "discipline" adalah "multidisciplinary" dan "interdisciplinary". Jika multidisciplinary mengasumsikan adanya pembahasan atas sebuah tema melalui pendekatan dan sudut pandang atas bidang studi masing-masing secara 
otonom, maka interdisciplinary dalam konteks pendidikan mencoba mengintegrasikan tema bahasan ke dalam beberapa mata pelajaran.

Pendekatan transdisipliner (transdisciplinary approach) lebih melihat sebuah tema bahasan bukan saja dari perspektif mata pelajaran, tetapi juga menimbang konteks kekinian dan kebutuhan siswa berdasarkan bakat dan minatnya. Dengan demikian, transdisciplinary approach dalam konteks pembelajaran membutuhkan keterampilan dan kreativitas guru yang luar biasa untuk memandang dan mengajarkan sebuah subjek/materi/mata pelajaran berdasarkan tema, konsep, sekaligus keterampilan yang sesuai dengan kehidupan nyata dan minat siswa dalam mendorong nilai-nilai kebaikan ke arah kebajikan yang pasti dan bertanggungjawab. ${ }^{1}$

Strategi penelitian lintas disiplin untuk menciptakan suatu pendekatan yang holistik". Dalam Simposium Internasional tentang transdisciplinarity yang diselenggarakan oleh $\mathrm{UNESCO}^{2}$, beberapa pakar mendefiniskan bahwa "transdisiplinaritas adalah konsep dan praktik pengetahuan yang terintegrasi, untuk menangani isu-isu penting berdasarkan prosedur tertentu secara integratif.

Konsep disiplin berhubungan erat dengan dua persoalan yaitu ketidakmengertian seseorang terhadap bahasa yang digunakan oleh disiplin ilmu itu sendiri, kemungkinan kedua adalah adanya pengertian bahwa bahasa yang digunakan oleh disiplin ilmu itu sepakat memperlakukan disiplin ilmu itu dengan ilmu yang berbeda". Secara sederhana transdiscilinary merupakan suatu proses yang dicirikan dengan adanya integrasi upaya dari berbagai disiplin (multydisciplines) untuk memahami suatu isu atau masalah. ${ }^{3}$

Gerakan transdisipliner secara resmi dicanangkan melalui suatu deklarasi, tahun 1994, ketika diselenggarakan kongres pertama transdisciplinary di Convenco da Arrabida, Portugal. Charter/piagam

${ }^{1}$ Ahsan Sofyan, "Pendekatan Transdisciplinary Sebagai Suatu Alternatif Di Dalam Memecahkan Masalah Pendidikan," ttp://andiaccank.blogspot.com/2011/10/ pendekatan-transdisciplinary sebagai. html, 2011, (24-maret-2016).

${ }^{2}$ UNESCO. 1998. "Transdisciplinarity: Stimulating Synergies, Integrating Knowledge" [Online]. Tersedia:http://unesdoc.unesco.org/images/0011/001146/ 114694eo.pdf [12 November 2011], h. 24 n.d.

${ }^{3}$ UNESCO. 1998. "Transdisciplinarity: Stimulating Synergies, Integrating Knowledge [Online]. Tersedia:http://unesdoc.unesco.org/images/0011/001146/ 114694eo.Pdf. (23 Maret 2016) Hal. 31 
yang ditulis dalam delapan bahasa (Inggris, Perancis, Portugis, Spanyol, Romania, Italia, Arab, dan Turki) berisikan preamble, 14 article dan satu artikel final ini menjadi "fundamental principles" landasan bagi pengembangan visi, ruang lingkup, penelitian, pendidikan, moral dan cara kerja masyarakat transdisipliner. Preamble berisikan enam pernyataan mengenai dunia ilmu pengetahuan, kehidupan masyarakat dunia, perkembangan teknologi yang melahirkan ketimpangan-ketimpangan dan ketidakmampuan menyelesaikan berbagai masalah kemanusiaan. Keempat belas artikel yang dirumuskan antara lain berkenaan dengan permasalahan realitas, posisi transdisipliner terhadap disiplin ilmu yang ada, objektivitas dan definisi keilmuan, filsafat, agama dan mitos, kebudayaan, pendidikan, ekonomi, etika, dan toleransi keilmuan. ${ }^{4}$

Dalam menjelaskan asas transdisiplinaritas pendidikan, mengemukakan bahwa pendidikan transdisiplin/transdisipliner tetap berasaskan pada pendidikan disiplin ilmu tetapi tidak dalam pengertian pendidikan disiplin ilmu yang tradisional. Pendidikan transdisipliner memiliki pandangan bahwa kepentingan umat manusia adalah kepentingan utama dan bukan kepentingan disiplin ilmu. Disiplin ilmu tidak boleh menjadi pembatas kotak cara berfikir, bersikap dan bertindak seseorang; disiplin ilmu yang diajarkan harus bersifat terbuka dan kebenaran yang diajarkan selalu berkembang. Penekanan pada aspek manusia ini bukan suatu yang baru dalam pendidikan tetapi dominasi penguasaan "scholastic knowledge" yang mendominasi kepedulian pada unsur manusia tersebut.

Menjadi keniscayaan bahwa subyek sekaligus obyek pendidikan tidak bisa dilepaskan dari manusia. Demikian juga transdisiplinaritas dalam pendidikan, makna yang digali dan dikembangkannya berorientasi pada pengembangan sumber daya manusia yang berkesinambungan. Oleh karenanya dengan pendekatan transdisiplinaritas ini, pendidikan dapat menjadi salah satu alternatif memecahkan kebuntuan keilmuan melalui sebuah proses perbaikan dan penyesuaian dengan lintas disiplin ilmu yang dikembangkan.

4 Said Hamid Hasan, “"Transdisciplinarity Dalam Pendidikan Dengan Referensi Khusus Pada Kurikulum"” (Seminar tentang Transdisciplinarity, Univeristas Negeri Jakarta, 29 Oktober 2007., n.d.). 
Tradisi pengembangan ilmu dalam masyarakat Islam umumnya sering mendikotomikan antara ilmu agama dengan ilmu umum. Padahal ilmu tersebut hanya alat untuk mendapatkan pemahaman bagaimana memanfaatkan kehidupan yang bermanfaat dan bermartabat. Sebagaimana dikemukakan Seyyed Hossein Nasr dalam Azra ${ }^{5}$, bahwa berbagai cabang ilmu atau bentuk-bentuk pengetahuan dipandang dari perspektif Islam pada akhirnya adalah satu, karena dalam Islam tidak dikenal pemisahan yang esensial antara "ilmu agama dengan ilmu umum/profan". Meskipun berbagai ilmu dan perspektif intelektual yang dikembangkan dalam Islam memiliki suatu hirarki, namun pada akhirnya hirarki-hirarki itu bermuara pada laut yang sama yaitu pengetahuan tentang "Yang Maha Tunggal".

Inilah alasan utama para ilmuwan Muslim kontemporer berusaha mengintegrasikan ilmu-ilmu yang dikembangkan oleh peradaban-peradaban lain ke dalam skema hirarki ilmu pengetahuan yang menurut Islam. Pada dasarnya tunggal/tauhid. Berkaitan dengan hal tersebut konsep ilmu dalam tradisi pendidikan Islam diorientasikan kepada keimanan kepada Allah SWT sebagai sumber ilmu, sehingga mampu membentuk pribadi yang bertakwa dan saleh secara pribadi dan sosial, tanpa harus memilah-milah ilmu tertentu.

Tujuan dikembangkan transdisiplinaritas ini bukan untuk membentuk suatu disiplin ilmu baru, melainkan sebuah pendekatan untuk membangun paradigma dan pemahaman yang diperlukan untuk memecahkan problem keilmuan dengan proses lintas disiplin dari berbagai perspektif yang berbeda dalam dinamika peradaban yang terus berkembang. Dengan melihat konsep ilmu di atas, pendidikan Islam memberi penegasan terhadap karakteristik ilmu yang dikembangkan, yaitu: pertama, penekanan pada pencarian ilmu pengetahuan, penguasaan serta pengembangan atas dasar ibadah kepada Allah SWT, sebagai sebuah proses yang berkesinambungan dan berlangsung seumur hidup (life long education). Kedua, penekanan pada nilai-nilai akhlak.

Di dalam konteks ini nilai-nilai kejujuran, sikap tawadlue, menghormati sumber pengetahuan dan sebagainya merupakan prinsipprinsip penting yang perlu dipegang teguh oleh setiap penuntut ilmu.

5 Azyumardi Azra, Pendidikan Islam: Tradisi Dan Modernisasi Menuju Millenium Baru (Jakarta: Logos Wacana Ilmu, 1999), h.xii. 
Ketiga, pengakuan atas potensi dan kemampuan seseorang untuk berkembang dalam suatu kepribadian. Hal ini menunjukkan bahwa setiap penuntut ilmu dipandang sebagai makhluk Tuhan yang perlu dihormati dan disantuni, agar potensi-potensi yang dimilikinya dapat teraktualisasikan dengan sebaik-baiknya. Keempat, pengamalan ilmu pengetahuan diletakan atas dasar tanggung jawab kepada Tuhan dan umat manusia. Artinya suatu pengetahuan bukan hanya untuk diketahui dan dikembangkan, melainkan sekaligus untuk dipraktikan dalam kehidupan sehari-hari. ${ }^{6}$

Setidaknya, sejumlah karakteristik pendidikan Islam di atas dapat menunjukkan betapa perlunya transinternalisasi budaya dalam proses pendidikan. Ia merupakan bagian dari rutinitas kehidupan sehari-hari dalam menjawab berbagai permasalahan yang disebabkan antara lain oleh hilangnya perhatian terhadap nilai-nilai etika dari para lulusan pendidikan. Tatakrama dan sopan santun dalam bermasyarakat mulai luntur dan tak berbatas lagi. Semua menjadi serba tumpang tindih. Tata kehidupan baik dalam hubungan sosial, ekonomi, politik dan budaya serba bersinggungan dan tumpang tindih. Sikap individualis membawa pada arogansi perilaku seseorang tanpa peduli terhadap lingkungan sosial. Sifat kemanusiaan manusia terdistorsi ke dalam egoisme individual dan sentimen kelompok yang membabi buta. Pendidikan hanya bermakna bagi pemenuhan intelektual semata dan kurang memperhatikan terhadap penanaman sikap. ${ }^{7}$

Untuk menjembatani berbagai persoalan di atas, pendidikan Islam menawarkan prinsip-prinsip transinternalisasi dengan menempatkan agama sebagai norma yang mutlak dalam memberikan landasan etis dan spiritualnya. Oleh sebab itu, penguasaan terhadap sains dan sumber-sumber pengetahuan lain bagaimanapun juga memerlukan landasan moral dan spiritual saat diaktualisasikan kepada masyarakat.

Tanpa adanya landasan/panduan ini akan memunculkan berbagai konsekuensi/dampak negatif yang menjadikan manusia semakin jauh dari nilai-nilai kemanusiaannya itu sendiri. Ilmu pengetahuan yang dikembangkan, jika sama sekali tanpa panduan

${ }^{6}$ Ibid., h.10.

${ }^{7}$ Imam Mawardi, “"Transinternalisasi Budaya Pendidikan Islam: Membangun Nilai Etika Sosial Dalam Pengembangan Masyarakat,"” Hunafa Jurnal Studi Islamika STAIN Palu Vol. 8, no. 1 (June 2011): h.30. 
moral-spiritual justru akan mendatangkan kemudharatan bagi kehidupan manusia dan alam semesta.

Manusia menjadi semakin terasing dengan potensi akhlak yang ada dalam dirinya dan aktifitasnya menjadi kosong dari nilai-nilai spiritual/ketuhanan. Dalam arti ini, pendidikan Islam erat hubungannya dengan sumber daya manusia (SDM). Dengan demikian dalam mengembangkan SDM yang unggul dan kompeten pendidikan hendaknya menghasilkan lulusan yang unggul dalam spiritualitas dan kepribadian sekaligus kompeten dalam keilmuan dan keterampilan.

Menurut Hadari Nawawi (1994) SDM adalah daya yang bersumber dari manusia, yang berbentuk tenaga, kekuatan atau energi. Sumber daya manusia mempunyai dua ciri, yaitu: 1) personal yakni berupa pengetahuan, perasaan dan keterampilan, 2) interpersonal yaitu hubungan antar manusia dengan lingkungannya. Emil Salim menyatakan bahwa yang dimaksud dengan SDM adalah kekuatan daya pikir atau daya cipta manusia yang tersimpan dan tidak dapat diketahui dengan pasti kapasitasnya. Beliau menambahkan bahwa SDM dapat diartikan sebagai nilai dari perilaku seseorang dalam mempertanggungjawabkan semua perbuatannya, baik dalam kehidupan pribadi maupun dalam kehidupan keluarga, masyarakat dan bangsa. Dengan demikian kualitas SDM ditentukan oleh sikap mental manusia. $^{8}$

Peningkatan kualitas SDM, menurut Azra9 ${ }^{9}$ dapat dilaksanakan dalam keselarasan dengan visi dan misi profetis Nabi, yakni untuk mendidik manusia, memimpin mereka ke jalan Allah dan mengajar mereka untuk menegakkan masyarakat yang adil, sehat, harmonis, sejahtera secara material maupun spiritual. Hal diisyaratkan dalam Q.S Saba [34]: 28

$$
\text { وَمَا أَرْنَلْنَاكَ إِلَّ كَافَّةً لِلنَّاسِ بَشِيرًا وَنَذِيرًا وَلْكِنَّ أَكْثَرَ النَّاسِ لَا يَعْلَمُونَ }
$$

${ }^{8}$ T. Z Djaafar, Pendidikan NonFormal Dan Peningkatan Sumber Daya Manusia Dalam Pembangunan (Padang: FIP UNP, 2001), h.2.

${ }^{9}$ H.M Arifin, Ilmu Pendidikan Islam: Suatu Tinjauan Teoritis Dan Praktis Berdasarkan Pendekatan Interdisipliner. (Jakarta: Bumi Aksara, 1993), h.55.

Analisis: Jurnal Studi Keislaman, Volume 17, No. 2 Tahun 2017 
"Dan kami tidak mengutus, melainkan kepada umat manusia seluruhnya, sebagai pembawa berita gembira dan sebagai pemberi peringatan"

Sebagai pendidik dan sekaligus Rasul, misi pertama Nabi Muhammad SAW dalam meningkatkan SDM adalah menanamkan akidah yang benar, yakni akidah tauhid untuk mengesakan Allah. Dalam kerangka tauhid ini, maka SDM yang diharapkan adalah manusia yang memiliki kualitas yang seimbang: beriman, berilmu (beriptek) dan beramal; cakap lahir batin; berkualitas secara emosional dan rasional, atau memiliki IQ, EQ dan SQ yang tinggi. Menurut $\mathrm{Azra}^{10}$, krisis dalam kualitas SDM terjadi ketika manusia tidak lagi mempertimbangkan dan mempedulikan harmoni.

Misi kedua adalah membangun masyarakat sosial-politik yang direfleksikan dalam Piagam Madinah dan juga membangun tradisi pendidikan Islam dengan fungsionalisasi masjid, tidak hanya sebagai tempat melakukan shalat, tetapi juga untuk melakukan pendidikan dalam pengertian seluas-luasnya. Dalam rangka meningkatkan kualitas SDM umat Islam saat itu beliau melakukannya dengan memberi keteladanan/uswah. Dengan demikian, peningkatan kualitas SDM merupakan bidang garapan pendidikan Islam. Bidang tersebut dirumuskan dalam tujuan pendidikan Islam.

Mujib dan Mudzakir ${ }^{11}$ mengatakan bahwa tujuan pendidikan Islam harus berorientasi pada hakikat pendidikan, yang meliputi beberapa aspek: (1) tujuan dan tugas hidup manusia. Bagaimanapun juga manusia diciptakan dengan membawa tugas dan tanggung jawab hidup tertentu. Tujuan diciptakan manusia hanya untuk mengabdi kepada Allah SWT. Indikasi tugasnya berupa ibadah (sebagai abd Allah), sebagaimana terdapat dalam al-Qur'an surat Al-an'am [6]: 162.

$$
\text { قُلن إِنَّ صَّلاتِي وَنُسُكِي وَمَحْيَايَ وَمَمَاتِي لِلَّهِ رَبِّ الْعَالمِيَنَ }
$$

Katakanlah: Sesungguhnya sembahyangku, ibadatku, hidupku dan matiku hanyalah untuk Allah, Tuhan semesta alam.

${ }^{10}$ Azyumardi Azra, Pendidikan Islam: Tradisi Dan Modernisasi Menuju Millenium Baru, h56.

11 Abdul Mujib and Jusuf Mudzakkir, Ilmu Pendidikan Islam (Jakarta: Kencana, 2008), h.71-72. 
Memperhatikan sifat-sifat dasar (nature) manusia, yaitu konsep tentang manusia sebagai makluk unik yang mempunyai beberapa potensi bawaan, seperti fitrah, bakat, minat, sifat dan karakter, (3) Adanya tuntutan masyarakat, baik yang berupa pelestarian nilai-nilai budaya maupun pemenuhan terhadap tuntutan kebutuhan hidupnya dalam mengantisipasi perkembangan dunia modern, (4) dimensi-dimensi kehidupan ideal Islam yang mengandung nilai keseimbangan dan keserasian antara kebutuhan duniawi dan ukhrawi.

Kualitas SDM menyangkut banyak aspek, yaitu aspek; sikap, mental, perilaku, kemampuan, intelegensi, agama, hukum dan kesehatan ${ }^{12}$. Semua aspek tersebut pada dasarnya menjelma ke dalam dua potensi yang masing-masing dimiliki oleh tiap individu, yaitu jasmaniah dan ruhaniah. Idealnya, aspek jasmaniah selalu dipandu oleh ruhaniah yang bertindak sebagai faktor pendorong yang muncul dari dalam diri manusia. Untuk mencapai SDM yang berkualitas, usaha yang paling utama adalah memperbaiki potensi dari dalam manusia itu sendiri. Hal ini menunjukkan bahwa kepatuhan terhadap diri merupakan tujuan dari pelaksanaan pendidikan Islam.

Sistem pendidikan Islam dalam rangka mewujudkan SDM yang berkualitas, harus mengorientasikan diri untuk menjawab segala tantangan yang muncul seiring dengan perkembangan zaman dengan mengkritisi sedemikian rupa perkembangan masyarakat. Pemenuhan kebutuhan tersebut dapat diatasi dengan reorientasi kurikulum pendidikan Islam, di mana pembelajaran dalam berbagai disiplin keilmuan (transdisiplin) harus diselaraskan dengan nilai-nilai dan diikat dengan spiritualitas, bukan hanya dilihat dari segi pengembangan pengetahuan belaka.

Inti penyelenggaraan pendidikan terdapat dalam kurikulum yang dikembangkannya. Berarti kurikulum merupakan jantung pendidikan. Kurikulum menjadi penting sebab dapat menentukan ke arah mana pendidikan akan ditentukan. Beberapa konsep kurikulum mengarah pada pengertian bahwa kurikulum tidak terbatas pada sejumlah mata pelajaran saja, tetapi mencakup semua pengalaman belajar (learning experiences) yang dialami peserta didik dan

${ }^{12}$ T. Z Djaafar, Pendidikan NonFormal Dan Peningkatan Sumber Daya Manusia Dalam Pembangunan, h.2. 
mempengaruhi perkembangan pribadinya. ${ }^{13}$ Oleh sebab itu, kurikulum harus dikembangkan secara holistik, yaitu dibangun dengan keseluruhan sistem sebagai satu kesatuan dari tujuan, isi, metode dan evaluasi.

Antara aspek satu dengan lainnya pun secara berkesinambungan saling mengisi. Kesinambungan sistemik ini, sebagaimana digambarkan Miller ${ }^{14}$ dapat dikembangkan ke dalam tiga aspek pendidikan holistik, yaitu balance (keseimbangan), inclusion (inklusi), dan connection (keterhubungan) atas hubungan pengembangan potensi emosional, fisikal, estetika dan spiritual pada diri manusia.

Nilai-nilai prinsipil pengembangan kurikulum holistik dapat dilihat dari ciri-cirinya yaitu:

1. Berorientasi pada pengembangan spiritual. Setiap proses dan praktik pembelajaran mencerminkan nilai keimanan dan ketauhidan

2. Pembelajaran diarahkan agar peserta didik menyadari akan keunikan dirinya dengan segala potensinya

3. Pembelajaran tidak hanya mengembangkan cara berfikir analitis/linier tapi juga intuitif

4. Pembelajaran berkewajiban menumbuhkembangkan potensi kecerdasan ganda/kompleks

5. Pembelajaran berkewajiban menyadarkan siswa akan keterkaitannya dengan komunitas, sehingga mereka tidak mengabaikan tradisi, budaya, kerjasama, hubungan manusiawi serta pemenuhan kebutuhan yang tepat guna

6. Pembelajaran berkewajiban mengajak peserta didik untuk menyadari keterhubungannya dengan alam, sehingga memiliki kesadaran ekologi

7. Kurikulum berkewajiban memperhatikan hubungan antara berbagai pokok bahasan dalam tingkatan yang bersifat transdisipliner, sehingga dapat memberi makna kepada peserta didik

13 Susilana and dkk, Kurikulum Dan Pembelajaran (Bandung: Jurusan Kutekpen FIP UPI, 2006), h.2.

${ }^{14}$ Jhon P Miller, The Holistic Curriculum. (Toronto: OISE Press, 1996), h.3. 
8. Pembelajaran berkewajiban mengantarkan peserta didik kepada keseimbangan antara belajar individual dengan kelompok, antara isi dan proses, antara pengetahuan dan imajinasi, antara rasional dan intuisi, antara kuantitatif dan kualitatif.

9. Pembelajaran adalah sesuatu yang tumbuh dan berupaya menemukan serta memperluas cakrawala; dan

10. Pembelajaran adalah sebuah proses kreatif dan artistic. ${ }^{15}$

Kurikulum holistik berupaya menjawab persoalan-persoalan yang ada dalam pendidikan khususnya hal-hal yang berhubungan dengan kebutuhan masyarakat saat ini yang cenderung kompleks dan tidak pasti. Persoalan kemasyarakatan ini memerlukan pengembangan kurikulum yang berlandaskan pada keilmuan transdisiplin. Kajian terhadap Standar Isi dan Standar Kompetensi Lulusan (SKL) yang dikembangkan oleh kurikulum transdisipliner setidaknya memberi peluang akan eksistensi dari masing-masing disiplin ilmu dan bukan hanya mencerminkan satu disiplin ilmu. Demikian pula kemampuan yang terumuskan pada SKL adalah kemampuan yang dipersyaratkan dan dikehendaki oleh berbagai disiplin ilmu yang kemudian dirangkum secara tematis. Kurikulum yang bersifat transdisipliner bertujuan membangun SDM dan menghasilkan peserta didik yang berwawasan luas, terbuka, mumpuni, kompeten dan berkepribadian dinamis. ${ }^{16}$

Berbagai tipologi filosofis dan pendekatan teoretis dalam pengembangan kurikulum tersebut, bukanlah merupakan perbandingan mana yang terbaik untuk dapat dipergunakan, tetapi lebih pada substansi kajian sesuai dengan tujuan pendidikan yang diharapkan. Dengan demikian, pengembangan kurikulum harus dikembangkan secara holistik atau menyeluruh untuk dapat mengembangkan potensi-potensi SDM yang berkualitas, baik secara keilmuan maupun kepribadian dan kualitas kehidupan sosial melalui sistem pendidikan Islam yang baik dan bermutu.

${ }^{15}$ Qomari. 2010. Pendidikan Holistik: Penumbuh Spiritualitas, [Online]. Tersedia: http://www.semipalar.net/artikel [12 Maret 2016]. h. 2 .

16 Said Hamid Hasan, "“Transdisciplinarity Dalam Pendidikan Dengan Referensi Khusus Pada Kurikulum.,” 


\section{Peranan transdisiplinari dalam memcahkan masalah pendidikan}

Seratus tahun terakhir para ahli pendidikan telah berbicara tentang pendekatan yang disebut sebagai kurikulum yang terintegrasi (integrated curriculum). Dan dalam seratus tahun terakhir ini pula kita mendapati tiga pendekatan penting dalam proses intergasi kurikulum, yaitu multidisciplinary, interdisciplinary, dan yang paling up date adalah transdisciplinary. Jika multidisciplinary mengasumsikan pembahasan sebuah tema bahasan dengan pendekatan dan sudut pandang bidang studi masing-masing, maka interdisciplinary mencoba mengintegrasikan tema bahasan ke dalam beberapa mata pelajaran. Sedangkan transdisciplinary approach lebih melihat sebuah tema bahasan bukan saja dari perspektif mata pelajaran, tetapi juga menimbang konteks kekinian dan kebutuhan siswa berdasarkan bakat dan minatnya.

Transdisciplinary approach membutuhkan keterampilan dan kreativitas guru yang luar biasa untuk memandang dan mengajarkan sebuah subjek berdasarkan tema, konsep, sekaligus keterampilan yang sesuai dengan kehidupan nyata dan minat siswa dalam mendorong nilai-nilai kebaikan ke arah kebajikan yang pasti dan bertanggungjawab. Transdisipliner bukanlah sebuah disiplin ilmu melainkan sebuah pendekatan, sebuah proses untuk memperluas pengetahuan dengan mengintegrasikan dan mentransformasikan perbedaan perspektif, (Massimiliano Lattanzi, 1998)". Berdasarkan pendapat tersebut, maka tujuan dari pendekatan transdisiplin adalah untuk membangun pandangan-pandangan yang diperlukan untuk mengeksplorasi makna baru dan sebuah sinergi.

Transdisiplin mempunyai manfaat tidak hanya digunakan untuk menghadapi masalah-masalah kompleks semata, tetapi juga untuk melihat adanya problem baru yang muncul akibat dari analisis yang mendalam dari proses interdisiplin.

\section{Fenomena Trandisipliner Dalam Pendidikan Tinggi}

Fenomena trandisipliner di dalam permasalahan pendidkan sangat berpengaruh pengembangan inovasi pendidikan di Indonesia terutama dalam bidang kurikulum secara teknis sudah mulai dilaksanakan di Indonesia yaitu dengan dicanangkannya model 
pendidikan berbasis karakter. Dalam judul penelitian tentang Pengaruh Model Pembelajaran Transdisciplinary Terhadap Karakter Siswa Pada Sekolah Dasar Internasional Berbasis International Baccalaureate.

Hasil observasi pendahuluan memberikan gambaran bahwa pengembangan inovasi pembelajaran yang diwujudkan dalam model dan desain kurikulum masih belum ideal dan relevan. Akibatnya konsep kurikulum dari dalam penguatan, pengayaan, pengembangan, perluasan, pendalaman, melalui adaptasi atau adopsi standar pendidikan baik dari dalam negeri maupun luar negeri menjadi tidak jelas. ${ }^{17}$

Untuk itu dibutuhkan sebuah model pembelajaran yang menunjukkan kejelasan konsep dalam pembentukan karakter siswa. Model pembelajaran yang dianggap dapat membentuk karakter siswa yang dikembangkan pada sekolah dasar internasional berbasis International Baccalaureate (IB) yaitu model pembelajaran Trandisciplinary atau transdisiplin. Mengapa harus model transdisiplin, IB menyebutkan bahwa "Trandisciplinary Focus on issues across learning areas, between them and beyond them, for the emergence of new and broader perspectives and for deeper understanding of the interrelatedness of complex issues." Pada IB, model ini terdiri dari 6 (enam) tema dasar yang mengandung makna isu-isu penting kehidupan serta menawarkan.

Keenam tema ini merupakan signifikansi global yang menciptakan sebuah kerangka kerja transdisciplinary yang memungkinkan siswa untuk meningkatkan melampaui batas-batas pembelajaran dalam wilayah subjek. Pengembangan model transdisiplin didasarkan pada filosofis yang "committed to structured, purposeful inquiry as the leading vehicle for learning". Khusus untuk program pendidikan dasar atau dalam program IB dikenal dengan program PYP (Primary Years Programme) ini menjadi kajian yang tentu sangat menarik dan penting, mengingat sesuai dengan arahan pemerintah melalui kementerian pendidikan nasional tentang pembentukan karakter perlu dilakukan sejak usia dini. Ini sesuai dengan yang diharapkan pemerintah, karena program PYP yang ada

\footnotetext{
${ }^{17}$ Cucun Sunaengsih, "Pengaruh Model Pembelajaran Transdisciplinary Terhadap Karakter Siswa Pada Sekolah Dasar Internasional Berbasis International Baccalaureate," Mimbar Sekolah Dasar Vol.2, no. 2 (2015): 171.
} 
pada IB merupakan program berstandar internasional dalam arti yang sesungguhnya, karena dalam program ini selain menerapkan pelajaran Bahasa Inggris sebagai satu dari mata pelajarannya, Bahasa Ibu, dalam hal ini Bahasa Indonesia- bila diterapkan di Indonesia, masih harus dipakai. Anak didik harus tetap dikenalkan dengan budaya lokal dan harus tetap diajak berpikir tentang apa yang ada di sekitar lokalnya. Namun pada saat bersamaan, program ini membuat anak didik untuk berpikir secara internasional dengan cara mengajak mereka untuk peduli akan situasi yang ada di dunia luar (Act locally, think globally). Juga dengan cara mengajarkan kepada anak didik adanya perbedaan di antara sesama, dan dengan cara menerapkan profil-profil manusia yang mengarah ke dalam kehidupan yang lebih baik.

Fenomena trandisipliner di dalam permasalahan pendidkan dalam judul integrasi ilmu alam (sains) dan agama berbasis kurikulum grass roots di perguruan tinggi islam dari berbagai kecapan yang harus dimiliki mahasiswa khususnya sebagai pelaku (subjek) transformator nilai-nilai (values) dan memiliki kemampuan life skill yang unggul akhir-akhir ini mengalami krisis antara apa yang diharapkan dengan kenyataan di lapangan. Kenyataan tersebut terkait dengan mutu PT di negeri ini. Departemen Pendidikan Nasional (2006: 61) mengungkapkan bahwa: ${ }^{18}$

Indonesia sesudah 61 tahun merdeka ironisnya mutu pendidikan belum juga menggembirakan. Mutu pendidikan di Indonesia sudah ketinggalan kurang lebih 30 tahun dibandingkan negara lain. Merostnya mutu pendidikan Indonesia sangat berpengaruh tehadap kualitas Sumber Daya Manusia (SDM) sebagai modal pembangunan bangsa di masa datang. Indek Pengembangan Manusia Indonesia (HDI) masih berada di peringkat ke-112 di antara 175 negara. Posisi HDI Indonesia bahkan berada di bawah Vietnam.

Ilustrasi ini menunjukkan rendahnya mutu pendidikan di Indonesia, selain itu seorang pakar pendidikan Indonesia menyatakan bahwa mutu pendidikan di Indonesia tidak saja terjadi pada pendidikan dasar (SD) melainkan juga terjadi pada perguruan tinggi. Hasil survai Rahim (2008: 184-185), Ia menjelaskan bahwa perguruan tinggi negeri

18 Anda Juanda, "Integrasi Ilmu Alam (Sains) Dan Agama Berbasis Kurikulum Grass Roots Di Perguruan Tinggi Islam," Scientiae Educatia Vol.3, no. 1 (2014): h.80. 
di Indonesia tidak ada yang masuk ranking perguruan tinggi berkualitas di wilayah Asia. Dari 50 perguruan tinggi yang disurvai hanya empat perguruan tinggi yang berkualitas berasal dari Indonesia, itupun tidak termasuk dalam kelompok 15 besar; ITB berada dalam peringkat ke-19, UI peringkat ke-32, UGM peringkat ke-37, Universitas Erlangga ke-38, dan Undip peringkat ke-42.

Sementara itu pembelajaran pendidikan agama Islam (PAI) dan pelajaran umum misalnya (sains dalam hal ini IPA) pada tataran implementasi baik di perguruan tinggi umum maupun di PTAIS (UIN, IAIN) belum mampu mengintegrasikan kedua keilmuan di atas secara utuh (holistic). Tuntutan keutuhan pembelajaran kedua keilmuan: ilmu alam dan IPA berdasarkan hasil Konfrensi Islam Internasional di Islamabad.

IAIN sejak berdirinya telah berupaya merancang kurikulum yang mencakup kedua jenis ilmu tersebut (perenial knowledge dan acquired knowledge). Tuntutan keseimbangan aplikatif kedua jenis ilmu ini di berbagai institusi baik pada pendidikan umum maupun pendidikan keagamaan antara perenial knowledge (ilmu-ilmu agama yang bersumber dari Qur'an dan Sunnah), dengan acquired knowledge (ilmu-ilmu yang bersumber dari ilmu eksakta/kuantitatif) masih terpisah atau terjadi dikotomi.

Persoalan dikotomi mengungkapkan bahwa serba dikotomis ini sekarang pun terdapat di negeri kita. Dikotomi antara ilmu pengetahuan alam dan teknologi pada satu pihak dengan ilmuwan sosial di satu pihak dan humaniora pada pihak lain, dalam masyarakat kita sekarang ini kita dapati pula dikotomi antara para ilmuwan yang didik di lembaga-lembaga pendidikan "umum" atau lembaga-lembaga pendidikan "sekuler" pada satu pihak dengan para ilmuwan yang dibesarkan di lembaga-lembaga pendidikan agama (Islam) pada pihak yang lain. Selanjutnya di kalangan cendekiawan ilmu-ilmu sosial pun terdapat dikotomi, yaitu dikotomi antara ilmuwan ilmu sosial yang berorientasi kualitatif pada satu pihak dengan ilmuan sosial yang berorientasi kuantitatif pada pihak yang lain.

Dalam menempatkan pengembangan SDM yang unggul dan berkarakter sebagai bagian penting dari misi pendidikan Islam, sudah menjadi sebuah kebutuhan untuk memformat fungsi pendidikan Islam harus menjadi garda terdepan dalam menyiapkan generasi-generasi brilian, berbudi pekerti yang luhur, serta mampu bersaing secara sehat 
dan sportif dalam percaturan global. Untuk itulah, pendidikan Islam secara paradigmatik harus mampu menunjukkan jati dirinya sebagai lembaga pendidikan yang mengajarkan keutuhan spirit yang diwarnai oleh dinamika perkembangan pelbagai disiplin keilmuan. Dengan demikian, kaidah ilmu tidak sekedar secara teoretis berhubungan dengan apa yang diusahakan dalam kehidupan, tetapi juga pemahaman dan penghayatan bagaimana kehidupan bermakna itu dilakukan berdasarkan nilai-nilai kearifan hidup.

Pendidikan Islam sebagai salah satu disiplin keilmuan yang mengkaji dan mentransformasikan nilai-nilai islami yang bersumber dari khasanah Islam dengan berbagai dinamika pemikiran didalamnya memunculkan pelbagai disiplin ilmu sebagai turunannya seperti ilmu Tarikh Tasyriee merupakan cabang dari ilmu hukum dan sejarah Islam. Pelbagai cabang disiplin ilmu sebagai hasil pengembangan ilmu yang lebih luas ini, tujuannya memudahkan dalam pengklasifikasian pengetahuan, bukan untuk memilah atau menggolongkan keunggulan salah satu ilmu tertentu, baik yang sifatnya ilmu-ilmu tentang agama maupun ilmu-ilmu umum lainnya. Pada dasarnya konsep keilmuan yang dikaji dalam Islam itu sama, yaitu ketauhidan yang akan memunculkan nilai akhlak mulia.

Adanya dikotomi ilmu antara ilmu-ilmu umum dan ilmu-ilmu agama pada perkembangannya berdampak negatif terhadap kemajuan umat Islam sendiri. Pada kerangka ini, menurut Baharuddin, dkk ${ }^{19}$ setidaknya ada empat masalah akibat dikotomi ilmu tersebut, yaitu: pertama, munculnya ambivalensi dalam sistem pendidikan Islam; kedua, munculnya kesenjangan antara sistem pendidikan Islam dan ajaran Islam; ketiga, terjadinya disintegrasi sistem pendidikan Islam; dan keempat, munculnya inferioritas dalam pengelolaan lembaga pendidikan Islam. Keempat nilai inilah yang dikritisi oleh para penyelenggara pendidikan Islam generasi baru sehingga muncul konsep pendidikan Islam interdisipliner. Antitesis dari pendidikan dikotomis adalah pendidikan non-dikotomis. Paradigma pengembangan keilmuannya adalah transdisipliner terutama dalam konteks integrasi/interkoneksi/harmonisasi antara ilmu agama dengan ilmu umum.

19 Baharuddin and dkk, Dikotomi Pendidikan Islam: Historitas Dan Implikasi Pada Masyarakat Islam (Bandung: PT Remaja Rosdakarya, 2011), h.244. 
Memperhatikan pendidikan Islam, yang secara teoretis tak terpisahkan dari pendidikan umum, Zamroni ${ }^{20}$ menjelaskan bahwa pendidikan Islam pun merupakan sebuah proses yang berhubungan dengan upaya untuk mengembangkan pada diri seseorang tiga aspek dalam kehidupannya, yakni pandangan, sikap, dan keterampilan hidup. Untuk merealisasikannya, menurut Zamroni bisa dilaksanakan di sekolah, luar sekolah dan keluarga. Kegiatan di sekolah direncanakan dan dilaksanakan secara formal dan ketat dengan mengacu pada kebijakan dan prinsip - prinsip yang sudah ditetapkan. Pengejawantahan di luar sekolah meskipun direncanakan dan diprogramkan juga tetapi pelaksanaannya relatif fleksibel. Di luar sekolah biasanya dibuat pelbagai pedoman yang disesuaikan dengan kebutuhan dan kondisi lokal. Pelaksanaan pendidikan dalam keluarga dilaksanakan secara informal tanpa tujuan yang dirumuskan secara baku dan tertulis. ${ }^{21}$

Dengan mendasarkan pada konsep ini, maka pendidikan Islam transisipliner dapat berupa pembudayaan atau "enculturation", yaitu suatu proses untuk mentasbihkan agar seseorang/sekelompok orang mampu dan berani hidup dalam/dengan suatu budaya tertentu. Dalam paradigma pendidikan Islam, kemampuan untuk hidup dalam suatu budaya senantiasa harus berdasarkan pada nilai-nilai etika atau moral yang merupakan pengejawantahan dari nilai - nilai akhlak mulia.

Dengan demikian, pendidikan Islam transdisipliner dikembangkan memberikan dengan dua peran, yaitu: Pertama, pendidikan Islam yang fungsinya sebagai transfer of value, yakni memberikan kontribusi kepada proses kulturisasi dalam pengembangan kepribadian dengan meletakkan etika untuk membangun diri individu, keluarga dan masyarakat berdasarkan nilainilai religiusitas dan normativitas yang berlaku di masyarakat. Kedua, pendidikan Islam menekankan pentingnya fungsi etika sosial sebagai bentuk nilai yang menjadi paradigma dalam mengarahkan seseorang berinteraksi dengan lingkungan sosialnya dan juga sebagai sasaran ibadah utama karena merupakan muara kesempurnaan ketakwaan

20 Zamroni, Paradigma Pendidikan Masa Depan (Yogyakarta: Bigraf Publishing, 2000), h.81.

${ }^{21}$ Mochtar Buchori, Ilmu Pendidikan Dan Praktik Pendidikan Dalam Renungan (Yogyakarta: Tiara wacana Yogya bekerjasama dengan IKIP Muhammadiyah Jakarta Press, 1994), h.13. 
seseorang yang diimplementasikan dalam kehidupan sosial masyarakat melalui rekonstruksi budaya. ${ }^{22}$

Pendidikan yang tepat adalah pendidikan yang tidak menekankan pada abstraksi bentuk pengetahuan lain akan tetapi harus diajarkan dengan pendekatan kontekstual, konkrit dan global. Pendidikan transdisipliner dibangun atas dasar reevaluasi peran intuisi, imajinasi, kepekaan dan tubuh dalam transmisi pengetahuan. Seaton (2002) menyatakan bahwa pendidikan harus memperluas tujuan tradisional yang hanya menekankan pada penguasaan materi. Pendidikan harus mengembangkan individu yang mampu berhadapan dengan dunia sosial, ekonomi, politik, budaya yang kompleks dan berubah-ubah. Kompleksitas adalah hukum alam. Saling berhubungan di antara pelbagai komponen yang kompleks juga merupakan hukum alam. Dalam konteks pendidikan Islam transdisipliner, semua aktivitas pendidikan merupakan alat yang dapat mengakomodasi pelbagai fungsi kehidupan manusia. ${ }^{23}$

Dalam konteks Islam, tujuan pendidikan transdisipliner itu menyiapkan manusia sebagai khalifah di muka bumi (Q.S. al baqarah [2]: 31). Allah memberikan manusia dengan berbagai potensi yaitu fitrah dan akal. Fitrah adalah kemampuan dasar/pembawaan, yang mengandung arti "kejadian". Fitrah berasal dari kata fatara yang berarti menjadikan. ${ }^{24}$ Fitrah adalah citra asli yang dinamis, ada pada sistem-sistem psikofisik manusia dan dapat diaktualisasikan dalam bentuk tingkah laku. Seluruh manusia memiliki fitrah yang sama, meskipun perilakunya berbeda. Fitrah manusia yang paling esensial adalah penerimaan terhadap amanah untuk menjadi khalifah dan hamba Allah di muka bumi. Dimensi lain dari fitrah adalah fitrah agama, intelek, sosial, susila, ekonomi, seni dan kemajuan. ${ }^{25}$

Akal (al-aql), menurut al-Attas bukan hanya rasio. Akal adalah fakultas mental yang mensistematisasikan dan menafsirkan fakta fakta empiris menurut kerangka logika tertentu dan memungkinkan

22 Imam Mawardi, “Transinternalisasi Budaya Pendidikan Islam: Membangun Nilai Etika Sosial Dalam Pengembangan Masyarakat,"” h.51.

${ }^{23}$ Said Hamid Hasan, "'Transdisciplinarity Dalam Pendidikan Dengan Referensi Khusus Pada Kurikulum,"” h.4.

${ }^{24}$ H.M Arifin, Ilmu Pendidikan Islam: Suatu Tinjauan Teoritis Dan Praktis Berdasarkan Pendekatan Interdisipliner., h.88.

${ }^{25}$ Abdul Mujib and Jusuf Mudzakkir, Ilmu Pendidikan Islam, h.53-57. 
sebuah pengalaman menjadi sesuatu yang bisa dipahami. Akal adalah salah satu aspek dari intelek dan bekerja bersama intelek. Intelek adalah entitas spiritual yang inheren dalam hati (al-qalb), yaitu menjadi tempat intuisi. ${ }^{26}$ Kedua potensi tersebut merupakan bekal dalam mengelola dan memanfaatkan dunia dengan sebaik-baiknya. Kemampuan yang diharapkan dalam pendidikan Islam transdisipliner, salah satunya adalah kemampuan memandang dunia sebagai suatu sistem di mana antara satu sama lain sama-sama mempunyai tugas dan fungsi yang berbeda tapi saling terkait. Sistem yang terkait ini diletakan pada substansi nilai-nilai keimanan dan perilaku manusia yang didasarkan pada nilai-nilai akhlak mulia dalam menjaga dinamika keselarasan kehidupan.

Sebagai ajaran (doktrin), Islam mengandung sistem nilai yang berlangsung dan dikembangkan melalui proses pendidikan secara konsisten menuju tujuannya. Sistem-sistem nilai ini kemudian dijadikan dasar bangunan pendidikan Islam yang memiliki daya lentur normatif menurut kebutuhan dan kemajuan masyarakat dari waktu ke waktu. Oleh karenanya, pendidikan Islam merupakan sistem yang akomodatif terhadap aspirasi umat Islam yang berorientasi kepada pelaksanaan misi Islam dalam tiga dimensi pengembangan kehidupan manusia, yaitu: (1) dimensi kehidupan duniawi yang mendorong manusia sebagai hamba Allah untuk mengembangkan dirinya dengan penguasaan ilmu pengetahuan dan keterampilan yang mendasari kehidupan Islam. (2) dimensi kehidupan ukhrawi mendorong manusia untuk mengembangkan dirinya dalam pola hubungan yang serasi dan seimbang dengan Tuhannya. Dimensi inilah yang melahirkan berbagai usaha agar kegiatan ubûdiah-nya senantiasa berada di dalam nilai-nilai agamanya. Dimensi hubungan antara kehidupan duniawi dan ukhrawi mendorong manusia untuk berusaha menjadikan dirinya sebagai hamba Allah yang utuh dan paripurna, menguasai ilmu pengetahuan dan keterampilan, sekaligus menjadi pendukung serta pelaksana (pengamal) nilai-nilai agamanya. ${ }^{27}$

Ketiga dimensi di atas, harus menjadi satu kesatuan yang terintegrasi dalam mencapai tujuan pendidikan Islam. Manusia sebagai

${ }^{26}$ Daud Wan, Mohd Wan, Filsafat Dan Praktik Pendidikan Islam Syed M. Naquib Al-Attas (Bandung: Mizan, 2003), h.159.

${ }^{27}$ H.M Arifin, Ilmu Pendidikan Islam: Suatu Tinjauan Teoritis Dan Praktis Berdasarkan Pendekatan Interdisipliner., h.30-31. 
subjek sekaligus objek pendidikan dikembangkan berdasarkan nilainilai yang juga sesuai dengan tujuan Islam. Pendidikan Islam sebagai wadah untuk memproses manusia menjadi khalifah di muka bumi dengan berbagai karakteristiknya didasarkan atas nilai kemanfataan tersebut. Oleh sebab itu, kesadaran menjadi khalifah harus dimulai dengan pengembangan diri sendiri (ibda "binafsi) melalui keteladanan dan memberikan kontribusi yang terbaik bagi kesejahteraan hidup umat manusia. Sebagai bagian dari masyarakat-bangsa yang multi budaya dan agama, kesadaran untuk memahami dan berperan secara aktif/ambil bagian dalam mengembangkan peradaban merupakan ciri pendidikan Islam transdisipliner. Ia bukan hanya bermaksud memecahkan satu problema demi satu kepentingan tertentu dan sesaat, tapi untuk kemaslahatan manusia dan perkembangan dunia secara global.

\section{E. Kesimpulan}

Transdisiplinaritas adalah suatu proses yang dicirikan dengan adanya integrasi berbagai disiplin (multy-disciplines) ilmu untuk memahami isu atau masalah dan bertujuan membangun paradigma yang dapat memecahkan problem keilmuan secara lintas disiplin dan perspektif yang berbeda dalam menjalani dinamika peradaban yang terus berkembang. Orientasi pendidikan Islam transdisipliner berupaya menjawab segala tantangan seiring dengan perkembangan zaman. Pengembangan kurikulum pendidikan Islam transdisipliner harus dikembangkan secara holistik agar dapat mengembangkan potensipotensi SDM yang ada baik ilmu, kepribadian maupun kehidupan sosial. Analisis paradigmatik pendidikan Islam transdisipliner dalam rangka pengembangan SDM yang unggul dan berkarakter harus menonjolkan pada keutuhan spiritual yang mewarnai dinamika perkembangan pelbagai disiplin keilmuan, berdasar pada kaidah tidak hanya teoretis tetapi juga praktis. Adapun fenomena trandisipliner di dalam permasalahan pendidikan dan contoh trandisipliner di Perguruan Tinggi yaitu pengembangan inovasi pembelajaran yang diwujudkan dalam model dan desain kurikulum masih belum ideal dan relevan. Akibatnya konsep kurikulum dari dalam penguatan, pengayaan, pengembangan, perluasan, pendalaman, melalui adaptasi atau adopsi standar pendidikan baik dari dalam negeri maupun luar negeri menjadi tidak jelas. Untuk itu dibutuhkan sebuah model pembelajaran yang 
menunjukkan kejelasan konsep dalam pembentukan karakter siswa. Model pembelajaran yang dianggap dapat membentuk karakter siswa yang dikembangkan pada sekolah dasar internasional berbasis

International Baccalaureate (IB) yaitu model pembelajaran Trandisciplinary atau transdisiplin. [.]

\section{Daftar Pustaka}

Abdul Mujib, and Jusuf Mudzakkir. Ilmu Pendidikan Islam. Jakarta: Kencana, 2008.

Ahsan Sofyan. "Pendekatan Transdisciplinary Sebagai Suatu Alternatif Di Dalam Memecahkan Masalah Pendidikan." http://andiaccank.blogspot.com/2011/10/pendekatantransdisciplinary-sebagai.html, 2011.

Anda Juanda. "Integrasi Ilmu Alam (Sains) Dan Agama Berbasis Kurikulum Grass Roots Di Perguruan Tinggi Islam.” Scientiae Educatia Vol.3, no. 1 (2014): 80.

Azyumardi Azra. Pendidikan Islam: Tradisi Dan Modernisasi Menuju Millenium Baru. Jakarta: Logos Wacana Ilmu, 1999.

Baharuddin, and dkk. Dikotomi Pendidikan Islam: Historitas Dan Implikasi Pada Masyarakat Islam. Bandung: PT Remaja Rosdakarya, 2011.

Cucun Sunaengsih. "Pengaruh Model Pembelajaran Transdisciplinary Terhadap Karakter Siswa Pada Sekolah Dasar Internasional Berbasis International Baccalaureate." Mimbar Sekolah Dasar Vol.2, no. 2 (2015): 171.

Daud Wan, Mohd Wan. Filsafat Dan Praktik Pendidikan Islam Syed M. Naquib Al-Attas. Bandung: Mizan, 2003.

H.M Arifin. Ilmu Pendidikan Islam: Suatu Tinjauan Teoritis Dan Praktis Berdasarkan Pendekatan Interdisipliner. Jakarta: Bumi Aksara, 1993. 
Imam Mawardi. "Transinternalisasi Budaya Pendidikan Islam: Membangun Nilai Etika Sosial Dalam Pengembangan Masyarakat." Hunafa Jurnal Studi Islamika STAIN Palu Vol. 8, no. 1 (June 2011).

Jhon P Miller. The Holistic Curriculum. Toronto: OISE Press, 1996.

Mochtar Buchori. Ilmu Pendidikan Dan Praktik Pendidikan Dalam Renungan. Yogyakarta: Tiara wacana Yogya bekerjasama dengan IKIP Muhammadiyah Jakarta Press, 1994.

Said Hamid Hasan. “"Transdisciplinarity Dalam Pendidikan Dengan Referensi Khusus Pada Kurikulum."” presented at the Seminar tentang Transdisciplinarity, Univeristas Negeri Jakarta, 29 Oktober 2007., n.d.

Susilana, and dkk. Kurikulum Dan Pembelajaran. Bandung: Jurusan Kutekpen FIP UPI, 2006.

T. Z Djaafar. Pendidikan NonFormal Dan Peningkatan Sumber Daya Manusia Dalam Pembangunan. Padang: FIP UNP, 2001.

Zamroni. Paradigma Pendidikan Masa Depan. Yogyakarta: Bigraf Publishing, 2000. 